\title{
Care and temporality: pediatric nursing in the Joint Permanence System of a teaching hospital
}

\author{
Cuidado e temporalidade: a enfermagem pediátrica em Sistema \\ de Permanência Conjunta de um hospital-escola \\ Cuidado y temporalidad: la enfermería pediátrica en el Sistema \\ de Permanencia Conjunta de un hospital escuela
}

\section{Helena Becker Issia Maria da Graça Corso da Motta ${ }^{a, b}$}

How to cite this article: Issi HB, Motta MGC. Care and temporality: pediatric nursing in the Joint Permanence System of a teaching hospital. Rev Gaúcha Enferm. 2020;41(esp):e20190170. doi: https://doi.org/10.1590/19831447.2020.20190170
Universidade Federal do Rio Grande do Sul (UFRGS), Escola de Enfermagem, Departamento de Enfermagem Materno-Infantil. Porto Alegre, Rio Grande do Sul, Brasil.

- Universidade Federal do Rio Grande do Sul (UFRGS), Escola de Enfermagem, Programa de Pós-Graduação em Enfermagem. Porto Alegre, Rio Grande do Sul, Brasil.

\section{ABSTRACT}

Objective: To understand, in the temporality, the care phenomenon of the child and family in the scope of Pediatric Nursing of a teaching hospital.

Method: This is a phenomenological and hermeneutical study which uses the existential focus of Martin Heidegger and Ricoeur's hermeneutical analysis. Interviews were carried out with nine nurses of the Pediatric ward of the Porto Alegre's Clinical Hospital and with a teacher of the Nursing School of the Federal University of Rio Grande do Sul involved in the implementation of Pediatrics, between December 2014 and June 2015.

Results: In the temporality of Pediatric Nursing, the care model has been designed as a Joint Permanence System. The following dimensions have been revealed: creation process, care proposal, teaching, evolution in the development of time.

Conclusions: Pediatric Nursing introduces a pioneer care model that guarantees and qualifies the presence of the family next to the hospitalized child. It reaffirms the originality, topicality and innovation of this knowledge and the way of performing the care actions. It may be disseminated and replicated in other contexts of care, teaching and research.

Keywords: Pediatric nursing. Child, hospitalized. Family. Nursing care.

\section{RESUMO}

Objetivo: Compreender, na temporalidade, o fenômeno cuidado à criança e família no mundo da Enfermagem Pediátrica de hospital-escola.

Método: Estudo fenomenológico-hermenêutico, utilizando-se o enfoque existencial de Martin Heidegger e análise hermenêutica de Ricouer. Entrevistadas nove enfermeiras da Pediatria do Hospital de Clínicas de Porto Alegre, e docente da Escola de Enfermagem da Universidade Federal do Rio Grande do Sul envolvida na criação da Pediatria, entre dezembro 2014 a junho 2015.

Resultados: Na temporalidade da Enfermagem Pediátrica o modelo de cuidado é concebido como Sistema de Permanência Conjunta. Desvelam-se as dimensões: processo de criação; proposta de cuidado; ensino; evolução no devir do tempo.

Conclusões: A Enfermagem Pediátrica inaugura modelo pioneiro de cuidado que garante e qualifica a presença da família à criança hospitalizada. Reafirma a originalidade, atualidade e inovação desse conhecimento e o modo de fazer o cuidado. Pode ser difundido e replicado em outros contextos de cuidado, ensino e pesquisa.

Palavras-chave: Enfermagem pediátrica. Criança hospitalizada. Família. Cuidados de enfermagem.

\section{RESUMEN}

Objetivo: Comprender, en la temporalidad, el fenómeno de la atención al niño y a la familia en el ámbito de la Enfermería Pediátrica de un hospital-escuela.

Método: Se trata de un estudio fenomenológico y hermenéutico, en el que se utiliza el enfoque existencial de Martin Heidegger y el análisis hermenéutico de Ricouer. Se entrevistaron nueve enfermeras del área de Pediatría del Hospital de Clínicas de Porto Alegre y a una docente de la Facultad de Enfermería de la Universidad Federal del Rio Grande do Sul, quien participó en la creación de la Pediatría, entre diciembre de 2014 y junio de 2015.

Resultados: En la temporalidad de la Enfermería Pediátrica, el modelo de atención se ha diseñado como un Sistema de Permanencia Conjunta. Se revelaron las siguientes dimensiones: proceso de creación, propuesta de atención, enseñanza, evolución en el devenir del tiempo.

Conclusiones: La Enfermería Pediátrica inaugura un modelo pionero de atención que garantiza y califica la presencia de la familia junto al niño hospitalizado. Además, reafirma la originalidad, actualidad e innovación de ese conocimiento y el modo de brindar la atención médica. Puede difundirse y replicarse en otros contextos de atención, enseñanza e investigación.

Palabras clave: Enfermería pediátrica. Niño hospitalizado. Familia. Atención de enfermería. 


\section{口INTRODUCTION}

Care in Pediatric Nursing permeates the living dimensions of the child, the family and the nursing team itself in the hospital context, a symbolic environment created in human interactions for building a shared therapeutic project. Taking a reflective look at this process reveals the need to address the disease not only in the essentially biological nature, but as an existential dimension of the person, with the inclusion of the family and the integrity of care.

Child and family are seen as a care unit in continuous development, experiencing situations of physical, emotional, social and spiritual vulnerability to the disease process ${ }^{(1)}$. In this dimension, in the meeting of three worlds - child, family and Pediatric Nursing - a universe of possibilities of care reveals itself, in which all are caregivers and caring beings. The family, in its journey of being an anchor and supporting the existential project of the child, needs to reach developmental stages in the construction of its role as provider of its care nucleus ${ }^{(2)}$.

The existential understanding of care reveals a temporal dimension peculiar and immanent to the human condition. Care gives rise to the Human Being and, at the same time, it is through care that the Human Being reaches its most legitimate expression. Human existence in its event has care as a driver. Care constitutes the Being, from which it can be said that the Being is $\mathrm{care}^{(3)}$. And time is the horizon of the Being. It is through the temporalization of the Being, in the course of its own existence, that the Being exists and imprints its mark on the world that it builds through the inalienable force of its Being that is care ${ }^{(4)}$.

In this perspective, in the Heideggerian conception, care is closely linked to the Dasein (the being-there). Dasein means the being in the world that understands itself from its existence. From the world the being is constituted, reflects and understands the several ways of relating, living and behaving. Another element is the notion of temporality of existence - past, present, and vision of the future, given that self-awareness itself occurs only through the internal experience of time ${ }^{(3-4)}$.

Concern is the existential element that moves the Being, being understood by the existential ontology as care $e^{(4)}$. In the incessant transcendent movement of being, concern-care gradually opens the Being to the world, impelling it to gobeyond. The construction of the being in its existence is a continuous "become by being" that is present and, in this existential movement, accompanies the being in its evolution in time and gives it the characteristic of transcendence ${ }^{(3-4)}$.
The everyday of the Pediatric Nursing of a teaching hospital in the course of the creation of a model of care (Joint Permanence System) is the central theme of this study. Such a model reveals itself as a Dasein (being-there), projecting itself into the temporality of its existence. This model has expression in the temporality, being an ongoing activity, and decisively marks the transcendence of care $e^{(3-4)}$.

Revisiting the meanings of Being, care and temporality of existence, articulating knowledge of the information achieved, the analogy is born between Dasein (being-there) and the lived world of Pediatric Nursing of Porto Alegre's Clinical Hospital (Hospital de Clinicas de Porto Alegre, HCPA). The intersubjective aspects and the ability of listening are valued as guiding assumptions for the research approach, under the perspective of the Phenomenology ${ }^{(5)}$.

Care is done in time. Care and time reveal themselves as inseparable existential dimensions that mark the way of being of the Living Being in the world ${ }^{(3-4)}$. Entering the world of child care, a fundamental prerogative states that health institutions and their teams can ensure the protection of the rights of children, adolescents and families, providing them with legitimate care. This happens by safeguarding the first condition of encouraging and enabling the presence of the family during hospitalization. With this initiative, as promoters of family development, they can provide the best care to children regarding their health needs ${ }^{(6)}$.

In Pediatric Nursing care, the inclusion of the family happens more frequently in the late 1970s. At the time, there were isolated efforts to ensure that the family could stay with the hospitalized child and, in Brazil, the HCPA made a pioneering proposal at the time of the conception of Pediatrics. A historic recovery refers to the finding of a common thread that follows this creation, since 1979, which is the Joint Permanence System (JPS), then conceived ${ }^{(7)}$.

By conquering the right to stay with the child and participate in the care actions, the family has a different space in the planning of the nursing work. The professionals reorganized the pediatric care to offer more than clinical interventions for the child, aiming at the integrality of care, and offering greater autonomy to the families, improving the satisfaction regarding the results of care ${ }^{(8)}$.

The theoretical and philosophical assumptions of this study are that the HCPA's Pediatric Nursing ward, viewed as a Dasein (being-there) in the existential perspective, goes through a historical evolution, integrating possibilities of continuous care over time, maintaining the philosophy of keeping children with their parents as the guiding thread of its existential project. 
Through phenomenology, it was intended to unveil the phenomenon of Pediatric Nursing care in the hospital context, in its continuous "becoming", which gives it identity over time - past, present and future - and, in turn, constitutes itself in a language of care, transcendental and authentic. Therefore, the guiding question for this research was the following: How is Pediatric Nursing, in the context of a teaching hospital, building its references and ways of caring in the temporality? The aim of this study was to understand, from the perspective of temporality, the phenomenon of child and adolescent care and care for the family in the Pediatric Nursing context of a teaching hospital.

\section{DETHODOLOGY}

A qualitative study with a phenomenological-hermeneutic nature, using Martin Heidegger's theoretical framework $^{(3-4)}$ and based on other existentialist philosophers, to unveil the understanding of a paradigm shift, in the perspective of temporality, of the phenomenon of child and adolescent care, and of care for the family, in the context of the Pediatric Nursing ward of a teaching hospital, with the JPS philosophy as the guiding thread of its existential project.

The paper is based on the Doctoral Thesis of the Graduate Nursing Program ${ }^{(9)}$, which was written at the Pediatric Nursing Service (Serviço de Enfermagem Pediátrica, SEPED) of the HCPA, RS, Brazil, a teaching hospital where the theoretical-practical activities of the Nursing School of the Federal University of Rio Grande do Sul (Escola de Enfermagem da Universidade Federal do Rio Grande do Sul, EENFUFRGS) take place. Nine nursing assistants from the four SEPED Pediatric Inpatient Units participated in the study, three of them from each decade since the inaugural year of Pediatrics in 1979; and one is a teaching nurse who worked in the conception and implementation of Pediatrics in the referred hospital.

The following inclusion criteria were established for the assistential nurses: to be performing their duties on child care and care for the family in one of the HCPA Pediatric Inpatient Units and, preferably, in the morning or afternoon shift, during the investigated period, as they work consecutively from Monday to Friday, every week. The exclusion criteria included were the following: being a nurse who provides care exclusively on weekends and holidays, during the investigated period, due to the fact that in this situation the work dynamics are different from the daily workday. These dynamics make it impossible to participate in differentiated and systematized activities, peculiar to participation in interdisciplinary or representative programs of work groups organized to provide care for children and families in singular existential moments.

The participants were selected by unit and invitation, after surveying the dates of the nurses' admission period, made available by the nursing heads of the pediatric units. A non-probabilistic or theoretical sampling was used ${ }^{(5)}$, and three participants from each decade since the conception of Pediatrics were chosen, in order to include participants from the entire SEPED. This procedure is justified because it is a research conducted in the natural setting, to obtain detailed knowledge and valuing the principle of the temporality of Pediatric Nursing.

Information was collected from December 2014 to June 2015, through a phenomenological interview. The interviews were previously scheduled and conducted outside the nurses' working hours, in a private environment at the HCPA or the EENFUFRGS, recorded by the researcher and transcribed in full.

For the analysis of the statements, the stages of Ricoeur's hermeneutic analysis were adopted ${ }^{(10)}$ : Initial reading of the text by reading and rereading to perceive the first meanings; Critical Reading to classify the essential meanings of the phenomenon; Identification of the Metaphor enabling a new meaning from the comprehension of the text; and Appropriation which made it possible, by understanding the text and the set of images of the projected lived world, to decipher the hidden meaning behind the visible sense.

The ethical requirements of Resolution No. 466 of December $12^{\text {th }}, 2012$ of the National Health Council were met, obtaining the approval from the Research Ethics Committee of the HCPA, under opinion No.924,228. The research participants voluntarily accepted the invitation to participate in the study by signing the Free and Informed Consent Form (FICF). The identities were preserved, ensuring the participants' anonymity, being represented by the letter " $P$ " from participant, followed by the sequence number of the order in which the interviews were conducted, for example, $\mathrm{P} 1, \mathrm{P} 2$, and so on.

\section{—RESULTS AND DISCUSSION}

From the process of hermeneutic analysis the central theme emerged: "Joint Permanence System: being in time", composed by the following dimensions: Creation process; Presence of the parents with the child: care proposal; Joint Permanence System and Teaching; and Evolution of the Joint Permanence System. The first dimension portrays the creation process and was built from the analysis of the teaching nurse's statement. The other dimensions portray the understanding revealed by the totality of the statements. 


\section{Joint Permanence System: being on time}

Revealing the history behind the journey of the HCPA Pediatrics ward, a characteristic marks its distinction among the other pediatric realities of the city of Porto Alegre( ${ }^{(7)}$. Pediatric Nursing is conceived based on the JPS - child care and care for the family, going beyond the biological view of health. Child care in the hospital context now has as its service philosophy the promotion and maintenance of affective interrelationships between parents and children, enabling responsible family members to stay with the child. This philosophical conception is the focus of the creation process.

\section{Creation Process}

The appointment of an EENFUFRGS teacher to be part of the multidisciplinary group involved in the conception of Pediatrics marked the history of the creation of a model of care exercised by the pediatric nurse in a health team. The creation process arises as a manifestation of the Being; it is its utmost expression. Through it, the Being understands how to be in the world, and moves to meet other Beings to make sense of its existence ${ }^{(4)}$. Practicing the ability to recognize the uniqueness of each Being and exercising solicitude, one builds and rebuilds oneself in the world that one creates. The Human Being creates the world ${ }^{(11)}$.

The decisions for the planning of the work required constant study, articulating the purposes of the conceived philosophy and the stipulated care with the rules that governed the physical structure of Pediatric Units. The professors tells that she started by studying

[...] the 'plans' to see how the staff, patients, family members would circulate. We had engineering, architecture, and then medical staff meetings (P1).

The dialogical process with the professionals involved in the planning mediated the technical knowledge with the required practical knowledge. Due to the size of the project, the professor had to assume considerable responsibility, as she represented the teaching of the EENFUFRGS, and the multi-professional group designated for planning was responsible for its insertion. The essence of the Being (Dasein), the "being-there" and the "being-with", reveals itself in caring ${ }^{(3-4)}$ for its work.

[...] I was there and it couldn't go wrong! The work was intended for assistance, teaching and research [...] we wanted Pediatrics to have a 'model team' for the future professionals who would look after the children (P1).
The need for overcoming is an impetus for the materialization of a peculiar project due to its genuine specificity and importance. It led to constant improvement, through knowledge - driving spring to meet the challenges of a creative process:

[...] was considered a nurse who worked only with Pediatrics! [...] there was no specific technical training! l learned 'from my life, working, I had little knowledge of structuring, but I studied, I studied hard (P1).

The meaning of the word"training"relates to a specifically human way of the Being for perfecting its aptitudes and faculties, designating the result of this process of becoming that does not take place in the form of a technical purpose, but emerges from the inner process of formulation, constantly evolving and improving ${ }^{(12)}$.

It is noticed that the innovations of a specific doing refer to its own doing, and the peculiarities are demanded from the Being to whom care is directed:

[...] medications, the context of the bath, nutrition for the various ages [...] this is all specific of the child [...] to structure, as a new need arose in the team, we called a professional [...] at that time it was all intuition! (P1)

In the creative process, art transcends technique and requires other categories, especially intuition and sensitivity. Intuition is"a clear and distinct view of something that does not appear clearly and distinctly in everyday reality". The artist sees something, in an intellectual way, which soon tries to represent in their work, in their artistic creation"(13:144).

Concomitant with the planning of the physical structure was the creation of the philosophical model, based on the conceptions of the theory of Social Pediatrics, inspired by the psychological theories that helped to explain the manifestations resulting from the emotional deprivation suffered by children when away from their parents. The participant reveals:

[...] the model began to organize itself from the set of situations that happened to children [...] it was found that in pediatric hospitals mothers were separated from children. The philosophical model was related to the ideals of Debrés Social Pediatrics. Already at that time Social Pediatrics was a model for us (P1).

However, the journey was marked by challenges until the institutional acceptance of a proposal that would definitely stop the separation of children from their family. 
The foundation stone of the JPS was laid, the beginning of a story.

\section{Presence of the parents with the child: care proposal}

The JPS consolidated itself as a philosophy of care, a new concept to be used in the area of knowledge of child and family health care. It remained faithful to the concern to protect the principles involved in the dialogical and affective relationship with children and parents. Concern is the essence of care, and care is the essence of the Being ${ }^{(3)}$.

In the ontological perspective, concern reveals itself as a responsibility assumed by the Being, capable of propelling it to the projective activity, which allows it to act using its creative capacity with authenticity. In Heideggerian language "the consistency of the Dasein does not lie in the substantiality of a substance, but in the 'being-in-itself of the self-existent, whose being was conceived as a concern"(4:829).

The concern with the family is the JPS's way-of-being. In its Pediatric mode of being-in-the-world, the JPS initially predicted that the family would only be present throughout the day, but, with the experience, the possibility of qualifying the presence of the family caregiver emerges, who participates in the activities:

[...] in the beginning the mothers were expected to be with the children without doing anything. Later they were expected to help in the hygiene of children [...] the concern that mothers breastfeed, feed, help to change the child, in short, daily activities (P1).

[...] the mother was able to say in the Family Group: "I thought I would never be able to take care of my daughter with all this! You helped me and today I can! I make dressings, nurse, better than you taught me!" [...] / say "you (mother's name) are right!" The work of nurses, this greater involvement, you discover potentialities in these families [...] the power of resilience is huge! This is an example of this transformative power, of this work that is done, but this comes with time, with an unmeasured time (P10).

Understanding "unmeasured time" (P10) reveals a singular learning. It happens in the sphere of the intersubjectivity of the dialogical moment, when presence and solicitude favor the other's autonomy to achieve their existential project. The unveiling of the personal transformation of the family caregiver, from the nurse's desire and success, shows the existential achievement of both. An experience of this nature cannot be objectified by a linear time, it occurs in the temporalization of each Being ${ }^{(4,11)}$.
Concern accompanies the creative process and makes it possible to go beyond. Being constituted by it,"the Dasein is already advanced in relation to itself. By being, it has already projected itself increasingly into certain possibilities of its existence and, in such existential projects, pre-ontologically co-projected something like existence and being"(4:859). This existential movement of transcending enables the creation of projects or models of care.

In the view of the Existential Ontology, the JPS's model of care can, by analogy, be compared to the hermeneutic circle of care, in which each new knowledge is added to the previous one, creating a new one, in its own transcendence, in an integrative movement successively ${ }^{(3-4)}$, and in the temporality:

This care model is not a top-down model! It was what was happening in the daily routine [...] there were changes, it happened in reality and had to be inserted, to be part of a new knowledge. Thus parents were allowed over time to stay with their children [...] the evolution of a reality that was being captured (P1).

[...] an underweight girl needed to use a feeding tube and the mother's concern was, when the girl went home with the tube, what she would do. So I [nurse] said: "No worries, we will guide you! You'll start inserting it with us for safety, so you won't have any doubt." Then it was okay (P6).

In the constant search for understanding, a procedure to go beyond and that reveals the transcendence of care, the hermeneutic circularity is at stake, as

"[...] the circle comes from a way-of-being of the Dasein [...] Understanding, whether 'theoretical' or 'practical', is concerned only with the being that can be encompassed by the seeing-around [...] the person can only be experienced "in fact" if the being was already understood. And, so, one has to consider what goes beyond the reach of ones' understanding and the procedure to go beyond"(4:859).

In the nurse's statement, the concern to know and understand the family-caregiver Being in the intersubjectivity of living is revealed:

The role of the whole team, Psychology, Social Work, medical approach [...] but the role of the nurse in the FSP [Family Support Program] is essential [...] it is a respectful, empathic care, knowing a little more, deepening a little more, need indeed to know the level of education, if the person has any disability, 
some difficulties [...] get to know who will be the potential caregiver, and then outline strategies (P10).

It is revealed that the transcendence movement of the model emerged from the coexistence of Nursing with families and from the learning experiences that emerged in the exercise of care. Nursing learning and the transfer to the daily practice of care for the family, including the preparation of those with children using life-sustaining technologies ${ }^{(14)}$, had the following as starting point:

[...] the parents' perspective. Care for the family [...] we didn't think anything at first. It was the families in their actions that taught us how they related and lived (P1).

In Pediatrics, there is a whole now-how about the educational process with families to demystify the handling of technologies [...] The discharge of children using technology equipment, there is a multidisciplinary team responsible for this [...] We have a family waiting for the nurse [from the child's hometown] to come to learn from us how to handle the central catheter; the parents will be trained in basic home CPR, how to ventilate, massage, this within the discharge program (P7).

For Pediatric Nursing, in its essential concern, which is care, the immanent possibility of moving towards the other as it is existentially "be-with" reveals authenticity. The conception of authentic care implies the relationship of coexistence and also of anticipatory solicitude, propelling the caregiver to free the other Dasein (being-there), with whom they live, to their own existence ${ }^{(3,11)}$. From this perspective, the presence of the family is recognized as essential in treating the child, and it is reiterated that the JPS is understood as a care proposal.

\section{Joint Permanence System and Teaching}

Having been created with the strong assumption that it would be a teaching model, the JPS was the scene of a living learning, full of unusual situations of care. This form of care that takes place in the hospital setting can be enlightened from teaching or educational practice, and teaching can also be invigorated in the practice of car ${ }^{(13)}$. In the mutuality of these interactions a singular learning emerges:

[...] soon after we realized that the children were not well away from their parents, and the family was not well away from the child [...] when the ECA started, it was adopted at the School. But the ECA was already old for us because there were many things that we already did (P1).
[...] from the beginning, the focus of Pediatrics was the child care and assistance for their families [...] did not start with the Statute of the Child, but long before! [...] later it was improved. It started from a very strong desire [...] Let's bring the family together! Our work philosophy [...] this evolution, the work with the family, is something that should never be missed! (P2)

[...] I started working here at the Clinicas, I identified with the way of care, the family being together all the time, the concern with the family [...] I think that Pediatrics since it was created had this, was based on, as we see from history, families staying with the children in the hospital; the topic of the Statute of the Child, which came later, strengthened some principles (P10).

Understanding the essence of Care means recognizing that "the can-be inherent of the Dasein proved to be resoIute $\mathrm{f}^{\prime \prime(4825)}$. It reveals that empowering oneself from a personal development perspective favors attitudes towards those with whom we share our existence. Faced with a situation, mechanisms are triggered by concern as for the essence of the Being - occupied together with another Being with whom it is directly involved. The solicitude enables to make a decision, includes acting "On"(4:825), and enables the Being to constantly update its care projects.

Gradually, this update was happening driven by the projective movements of the Pediatric Nursing Being. In Heidegger's philosophy, it is in the movement of thinking and creating care projects that the construction of knowledge occurs ${ }^{(4)}$. The JPS is perceived as a model that now gives visibility to Pediatric Nursing. This projection enabled empowerment and self-confidence as a differentiated care area. Linked to the beginning of the Graduate level at the EENFUFRGS, it reaffirms the academic-assistance character of such proposal, and continues to evolve in temporality:

History fits with the timeline of power that pediatric nurses have gained [...] the work has given national visibility! Everyone wanted to say that here we had mothers present! This power of nurses began [...] together with the Graduate School (P1).

[...] if it is going very well, things are happening, if it is always in touch with the advances, but it is known that this is because it is a teaching hospital [...] the UFRGS helps a lot in the learning process, continuing to update to also be able to contribute (P7).

The role of the academy is pulsating in the journey of a teaching hospital: 
[...] it makes a difference to be a teaching-hospital. This foundation of child care and care for the family came from school, I graduated from the UFRGS and learned it from school and it has been done all these years (P5).

[...] / copy the teachers a lot [...] I bring to my life that, in general, the teaching at the UFRGS contributed a lot [...] to my training as a pediatric nurse. The discussions that took place, this look at child care and care for the family, even if it was theoretical, but I imagined: "this I would like to do if I have the opportunity" (P9).

In the teaching of Child Care, a new philosophical framework is unveiled. It is a contrast between the gaze cast on the child and not on the child's disease:

[...] when /learned Pediatrics, the important was the disease, not the child! Ilearned from my experiences, from my life (P1).

[...] our School gave this foundation. When I attended the Pediatric Nursing Subject, I experienced it all! This art, the work with children and care for the family. And it was such a natural thing, so that I started working in another institution, I felt weird about pushing away the family, the child was treated, it was the child's disease (P2).

Decently caring for the Being in its entirety includes an "action that transcends the framework of biology and the individual's corporeity and requires the attention and development of other constitutive dimensions of the human being ${ }^{\prime \prime(13: 39-40)}$. In temporality, there is a paradigmatic change in the way of seeing and understanding the being-in-theworld facing illness, hospitalization and treatment, including the family in equal measure.

\section{Evolution of the Joint Permanence System}

The JPS model was innovated since its creation and implementation, but remains true to its common thread. Over time, there is a resignification in the way of expressing the look at the insertion of the family in pediatric hospitalization: looking at the family as caregiver of the child, but also in need of being cared:

In this journey [...] how much this was rescued, systematized some issues, and that further facilitated this work, the child as a developing being that has all its particularities, and the family also as focus of care (P10).

[...] you don't provide assistance only to the child, but to the family! It's the caregiver, the father, the mother, or a grandmother! Having that perspective too: you take care of the child, but you also take care of the family! This is an advantage of our Pediatrics (P9).

Sensitive rethinking about the follow-up of the child generates a flexibility proposal, in which the presence of the family gains more space, time and conditions:

[...] this is a construction, it has always been so since it was created, with the presence of the parents, but things have been evolving! [...] this space was obtained for further growing, to give more conditions. Before the parents had to sit in a chair, nowadays they sit in an armchair, they can sleep, more things are allowed now: consider them with care too (P5).

Nurses, moved by knowledge as a way-of-being, take attitudes that assume the meaning of fighting without fading, aiming at what they are concerned with:

[...] in our Pediatrics, from the beginning this was very much discussed! Some professionals thought that the constant presence of the family was annoying, but this changed! It changed thanks to nursing, our persistence, our insistence that this is important (P2).

There is a subtle but fundamental difference between stimulating family participation in child care and the idea that the parents have a duty to do the procedures that the team thinks, or themselves feel, they are capable, or the opposite extreme, that the team is the only responsible for them:

[...] they can't be required to be there to do nursing care! [...] but to promote a care that the mother is there for the child, accompanying, guiding, being available! Not with the idea of competition, they are different roles and they can't be mixed! He is still that mother's son (P5).

A wise finding is learned when nurses understand about existing with the other - family caregiver:

There are several times to include the family into child care, in a simple bath or a bedside toy. Even letting the mother lay with her son in bed, to give her affection, the warmth the child needs. Removing rules that are so enforced! (P8).

The solicitude of this genuine attitude of nurses is understood as they try to understand the uniqueness of each being revealed in their behaviors, possibilities and strengths. In the Heideggerian perspective, the Being, when understanding itself and putting itself in the place of another with whom 
it coexists, "elaborates and falls apart according to what the Dasein's way-of-being is"(4:69-71), and in a movement of understanding and solicitude, is willing to understand its needs.

This understanding is revealed in the nurse's thoughts, when she says that

[...] each caregiver is different [...] they think the child is here and they need to take care of him/her. But no! The child belongs to that father, mother, caregiver, and will be back to home. We can't force them to do the things we think that should be done! [...] We can guide the family, but not make demands [...] The child is not ours (P4).

In the incessant movement to get to know the beings that inhabit the JPS better, nurses achieve a significant learning that, in extension, can be reflected in the way they interact with these individuals. Knowing the Being indicates that"its elaboration requires the explanation of the ways of directing the gaze to the being, of understanding and conceptually grasping its meaning, the preparation of the possibility of the correct choice and the elaboration of the genuine way to access this being ${ }^{\prime \prime(4.45)}$, resulting in unique dialogic spaces of learning and care.

Nurses reach the understanding that

[...] family and child urge us to grow, to seek greater knowledge and a better approach [...] the team needs to be more qualified to take a more therapeutic approach that does not take it personally, but understands how the family works. [...] there had been a lot of reflection in recent years on this! (P10).

The JPS shows the emphasis of interdisciplinary work, an attribute valued by the institution and evaluated as positive by Pediatric Nursing over time. Teams that are more open to integrated work initiatives build and rebuild current practices in defense of the rights of hospitalized children and adolescents, extended to the family. This assumption is that "advocating for and focusing on the patient, even having to face conflicts with colleagues or families, requires this moral courage" ${ }^{\prime \prime(15: 231)}$.

Thus, the creation of the Program for the Defense of Hospitalized Child and Adolescent Rights (Programa para Defesa dos Direitos da Criança e do Adolescente Hospitalizados, PDDCAH) emerges as a historical milestone, a pioneer in the academic and hospital settings, understood as support for the maintenance of the guiding assumptions of care:

[...] it's something more, it's an advantage of Pediatrics [...] in the sense of a growing that is for our children and service (P9).

[...] The Program emerged not only with the Statute of the Child, our concern pre-dates the Statute of the Child. The
ECA did not exist and when it was nationally approved, we already supported family staying with the children! [...] with all the concern to respect children's right, their individuality, to worry about their pain, among others (P2).

For being a Pediatric ward inserted in a general hospital, ensuring the rights of children and adolescents, whatever the location of the institution, was and is the basic premise that underlies the creation and implementation of the Program for

[...] prevention of institutional ill-treatment. A Pediatric ward within a general hospital, where processes are thought based on adults, not children [...] The child goes to the OR, not a child OR. The Defense Committee aims to direct: is there any problem, how will it be resolved? The individuals who participated in the process gather and study together how to improve care (P6).

It is necessary to consider the peculiar universe of the child to understand it, with the concern of providing a care focused on their real interests. The use of the concept "child's best interests" refers to the premise that any decision concerning the child's health should be the one in which the benefits to the child outweigh the potential harm, and where the focus is on the children and their wellbeing, not of the family or guardians ${ }^{(15)}$.

Another program that met the JPS's philosophy is the Child Protection Program for victims of domestic violence. It focuses on the right to protection against any form of discrimination, neglect or abuse and the right to respect for the physical, mental and moral integrity of the child. The participants recall that

[...] 20 years ago, child abuse was not so openly addressed. A Pioneer Experience [...] the Protection Program helps a lot in both protecting children and helping parents protect them (P4).

[...] a few years ago, there were situations where we suspected something could be happening, many times we could not prove [...] the child was discharged and we were anguished. Today is different, professionals are able to notice the ill-treatment and to make referrals (P7).

Encouraging oneself to take a different position in defense of the child denotes a responsibility characterized as broadening of consciousness and taking action with greater autonomy ${ }^{(4)}$. Thus, "in order for this to happen, distribution of knowledge, inter-sectoral learning and care management in networks are essential, envisaging multidimensional care $^{\prime \prime(16: 5)}$. Sharing new positions and growing mutually, the 
health team is restructuring before identified vulnerability situations, and in a movement of transcendence - to go beyond - the team adopts actions to support the child and the family:

[...] it's possible to save the child who was hospitalized with bronchiolitis, will be treated and go home [...] let's say the mother is 14 years old, has a history of drug abuse, had a partner and already has another, it is possible to see a range of situations that put this child in conditions of a critical vulnerability! You have to look beyond the clinical issue, to the whole more contextual issue (P10).

Responsibility had a primary point in the matter of care. It is necessary to overcome the dilemma between science and wisdom, since it integrates scientific elements related to the knowledge of the human being, both physiologically and anatomically, as well as attitudinal ${ }^{(4,13)}$. In the philosophy perspective, "the purpose of wisdom is ultimately the happiness of the man and the community."(13:36).

From this perspective, one of the participants reveals that

[...] in the case of maltreatment, we try to protect the child by guiding the family about what is happening and why it is happening. It is not always easy for a family to change its life structure [...] and monitors the child for a while after discharge (P4).

In this evolutionary process, Pediatric Nursing unveils its future projects. Teaching-care integration activities are valued for nurses by the recognition of the academy and constant stimulation for new experiences:

[...] it's a continuation of assistance! The professionals know what they are doing, transmitting to the family member, the team or the students [...] The work is being sent to an event, will be disclosed and published (P3);

[...] we feel valued in our work, the colleague going to the Nursing School to give a class and knowing the repercussion [...] can make more nurses, who are graduating, be willing to follow this path of Pediatrics (P5).

However, there is still "a need to identify and challenge the institutional barriers so that an ethical setting and an attitude of respect can be established in the workplace"(15:231) for the best interests of the child. Several proposals indicate the Pediatric Hospital and Adolescent Unit as the creation of institutional spaces for the expansion of child and adolescent care, bringing them together in an area with specific infrastructure:
[...] this difficulty is felt, such as the restricted hours in the Operating Room [...] we can't forget the fundamental, they are children [...] That is the essence! They should be seen with priority by the people from Pediatrics (P6);

[...] studies have been done in line with the Defense Program [...] Pediatrics never forgot this proposal [...] it would be ideal to have a Pediatric Hospital [...] Maybe in a few years it will be possible to achieve this dream [...] and have an Adolescent Unit (P10).

For the full exercise of care, some pillars are essential. They concern dedication and technique, science and wisdom, theoretical and practical knowledge in the context of an institutional model that enables favorable structural conditions for the care ${ }^{(13)}$. In this context, interdisciplinary research studies on pediatric ethics take on a decisive role in solidifying the multi-professional approach ${ }^{(15,17)}$.

\section{口 FINAL CONSIDERATIONS}

Care is done in time, and it was revealed in two different ways: linear time shows the events that are present in the journey of Pediatric Nursing, driven by the understanding and creative capacity of the builders of this story; and the horizon of time, in which the nurse Being builds its way of being in the world. The course of Pediatric Nursing is revealed as a Dasein (being-there), projecting itself into the temporality of its existence. It has the possibility of expression in self-temporization, in an activity always in progress, and emphasizes the existential character of the human condition: care.

The creation of the JPS was born as a movement that integrated several worlds of the health and education field, from the UFRGS and the HCPA. It had a nurse as craftswoman, a professor at the EENFUFRGS. This particularity transcended to the moment of creation and has influence until today, in the form of teacher-care integration. Reliving the journey, it is identified that Pediatric Nursing was born at that moment when the model of care was conceived, keeping under its care the work conceived in its daily exercise.

This research revealed the perspective of nurses, which could be considered a limitation when approaching care as a protagonist, since there are other elements involved in the care process, such as the family, the child and the professionals. However, it is noteworthy that this model can be disseminated and replicated in other contexts of care, teaching and research.

The JPS care model in Pediatric Nursing is innovative because it transcends child care and includes the family in the hospital context in a unique way. It goes through time 
and remains as a guiding thread throughout its existence. Over time, technologies, programs and care strategies were incorporated to meet the demands of the Beings cared for. Phenomenology made it possible to understand this world, showing the objectivities and subjectivities that emanate from this world, reaffirming the originality and innovation of this knowledge and the way of doing: care.

\section{REFERENCES}

1. Santos PM, Silva LF, Depianti JRB, Cursino EG, Ribeiro CA. Nursing care through the perception of hospitalized children. Rev Bras Enferm. 2016 JulAug;69(4):646-53. doi: http://doi.org/10.1590/0034-7167.2016690405i

2. Yakuwa MS, Andrade RD, Wernet M, Fonseca LMM, Furtado MCC, Mello DF. Nurses' knowledge in child health primary care primary. Texto Contexto Enferm. 2016;25(4):e2670015. doi: https://doi.org/10.1590/010407072016002670015

3. Heidegger M. Todos nós... ninguém: um enfoque fenomenológico do social. São Paulo: Moraes; 1981.

4. Heidegger M. Ser e tempo. Campinas: Ed Unicamp; Petrópolis: Vozes; 2012.

5. Poupart J, Deslauriers JP, Groulx LH, Laperrière A, Mayer R, Pires AP. A Pesquisa qualitativa: enfoques epistemológicos e metodológicos. 4a ed. Petrópolis: Vozes; 2014.

6. Araújo JP, Silva RMM, Collet M, Neves ET, Toso BRG0, Vieira CS. História da saúde da criança: conquistas, políticas e perspectivas. Rev Bras Enferm. 2014 novdez;67(6):1000-7. doi: https://doi.org/10.1590/0034-7167.2014670620
7. Nunes DM. Percepção e estado emocional da mãe, relativos à assistência hospitalar prestada a seu filho no sistema de permanência conjunta [dissertação]. São Paulo (SP): Universidade Federal de São Paulo; 1986.

8. Hill C, Knafl KA, Santacroce, SJ. Family-centered care from the perspective of parents of children cared for in a Pediatric Intensive Care Unit: an integrative review. J Pediatr Nurs. 2017. doi: https://doi.org/10.1016/j. pedn.2017.11.007

9. Issi, H B.0 mundo vivido da enfermagem pediátrica: trajetória de cuidado [tese]. Porto Alegre (RS): Universidade Federal do Rio Grande do Sul; 2015.

10. Ricoeur P. Interpretação e ideologias. $4^{2}$ ed. Rio de Janeiro: F. Alves; 1990.

11. Stein E. Mundo vivido: das vicissitudes e dos usos de um conceito da fenomenologia. Porto Alegre: EDIPUCRS, 2004.

12. Gadamer H. Verdade e Método I. 10 Ed. Petrópolis: Vozes; 2014.

13. Torralba FR. Antropologia do cuidar. Petrópolis: Vozes; 2009.

14. Nataraj C, Rodriguez N, Dokken D. Partnering to prepare families of children who are technology-dependent for home care. Pediatr Nurs. 2017;43(6):299-302.

15. Santos RP, Garros D, Carnevale F. Difficult decisions in pediatric practice and moral distress in the intensive care unit. Rev Bras Ter Intensiva. 2018;30(2):22632. doi: https://doi.org/10.5935/0103-507x.20180039

16. Silva APF, Backes DS, Magnago TSBS, Colomé JS. Patient safety in primary care: conceptions of family health strategy nurses. Rev Gaúcha Enferm. 2019;40(esp):e20180164. doi: https://doi.org/10.1590/19831447.2019.20180164

17. Carnevale FA, Campbell A, Collin-Vézina D, Macdonald ME. Interdisciplinary studies of childhood ethics: developing a new field of inquiry. Child Soc. 2015;29(6):511-23. doi: https://doi.org/10.1111/chso.12063

\section{- Corresponding author:}

Helena Becker Issi

E-mail:hissi@hcpa.edu.br

\section{Associate editor:}

